\title{
ANGKA KEJADIAN UNDESENSUS TESTIS DI RSUP PROF DR. R. D. KANDOU MANADO PERIODE JANUARI 2013 - DESEMBER 2015
}

\author{
${ }^{1}$ Henry William Burhan \\ ${ }^{2}$ Ainun Aschorijanto \\ ${ }^{2}$ Ishak Lahunduitan \\ ${ }^{1}$ Kandidat skripsi Fakultas Kedokteran Universitas Sam Ratulangi \\ ${ }^{2}$ Bagian Bedah Fakultas Kedokteran Universitas Sam Ratulangi \\ Email: \\ henrywilliamburhan@yahoo.com
}

\begin{abstract}
Undecended testicle (UDT) is a failure of the testes to descend into the scrotum, and is the most common genital disorder on infants. The predispositions are prematurity, low birth weight and estrogen usage during the first trimester of pregnancy. UDT can be diagnosed through physical examination or laparascopy. The usage of hormonal therapy for UDT is still a controversial issue. Orchidopexy is the most common surgical intervention used for UDT. The objective of the study was to indentify the number of undescended testicle cases in Prof. Dr. R. D. Kandou Central General Hospital Manado in 2013 - 2015. This study was a retrospective descriptive design, the sample is obtained from all the medical records of patients with undescended testicle in medical record installation of Prof. Dr. R. D. Kandou Central General Hospital Manado. Study shows that there are 37 cases of undescended testicle on $2013-2015$.
\end{abstract}

Keywords: undescended testicle, orchidopexy

\begin{abstract}
Abstrak: Undesensus testis (UDT) adalah kelainan genitalia kongenital tersering yang ditemukan, ditandai dengan tidak turunnya testis ke dalam skrotum. Predisposisi terjadinya UDT yaitu prematuritas, berat badan lahir rendah, dan penggunaan estrogen pada trimester pertama kehamilan ibu. Diagnosis UDT dapat ditegakkan melalui pemeriksaan fisik atau laparaskopi. Penatalaksanaan UDT menggunakan terapi hormonal masih dalam kontroversi. Tindakan yang paling sering dilakukan adalah orchidopeksi. Penelitian ini bertujuan bertujuan untuk mengetahui angka kejadian undesensus testis di RSUP Prof. Dr. R. D. Kandou Manado periode 2013 - 2015. Penelitian ini merupakan penelitian retrospektif deskriptif dengan melihat data pasien di instalasi rekam medik RSUP Prof. Dr. R. D. Kandou Manado. Hasil penelitian menunjukkan angka kejadian undesensus testis di RSUP Prof. Dr. R. D. Kandou Manado periode 2013 - 2015 sebanyak 37 kasus.
\end{abstract}

Kata kunci: undesensus testis, orchidopeksi

Undesensus testis (UDT) adalah kelainan genitalia kongenital yang paling sering ditemukan. Pada kelainan ini, testis tidak turun ke dalam skrotum. Angka kejadiannya yaitu pada 4-5\% bayi laki laki dengan umur kehamilan cukup, dan 20$33 \%$ pada bayi laki laki prematur. ${ }^{1-6}$
Terjadinya kelainan dari kontrol hormon atau proses anatomi dalam proses desensus testis secara normal dapat menyebabkan UDT. ${ }^{1-3,7-9}$

Faktor predisposisi terjadinya UDT adalah berat badan lahir rendah, bayi prematur dan terpaparnya estrogen pada 
ibu selama trimester pertama kehamilan. $^{3,4,7}$

UDT dapat dibedakan menjadi UDT palpable dan nonpalpable. Diagnosis UDT dapat ditegakkan melalui pemeriksaan fisik, namun dapat digunakan laparasokopi untuk menentukan posisi testis jika testis tidak teraba. $1,5,6,10,11$

UDT dapat terjadi unilateral atau bilateral, dan sering ditemukan pada bayi bayi dengan kelainan hormonal. Namun pada kebanyakan bayi, penyebab UDT tidak diketahui, namun rendahnya kadar androgen dicurigai sebagai penyebab utama. 10

Testis dapat turun spontan ke dalam skrotum pada usia tiga sampai enam bulan. $^{4,10}$ UDT dapat mengakibatkan penurunan kesuburan, torsio testis, hernia inguinalis dan meningkatnya resiko keganasan sel germinal. ${ }^{1-4,9-14}$

Tindakan yang paling sering dilakukan adalah orchidopeksi. ${ }^{1,6,12}$ Terapi operatif sebaiknya dilakukan pada usia satu sampai dua tahun. 2,5,6,12 Komplikasi paling sering dari orchidopeksi adalah atrofi testis, namun terjadi pada persentase yang kecil. ${ }^{1}$

Pada penelitian di Rumah Sakit Cipto Mangunkusumo Jakarta periode 2002 2010, diperoleh sebanyak 56 pasien didiagnosis UDT saat masuk rumah sakit, dan sebagian besar pasien UDT datang berobat pada usia satu tahun. ${ }^{3}$

Penelitian ini bertujuan untuk mengetahui angka kejadian undesensus testis di RSUP Prof. Dr. R. D. Kandou Manado periode Januari 2013 - Desember 2015.

\section{METODE PENELITIAN}

Penelitian ini merupakan peneitian retrospektif deskriptif yang dilakukan di instalasi rekam medik RSUP Prof. Dr. R. D. Kandou Manado. Sampel penelitian adalah seluruh data dari catatan rekam medik pasien dengan diagnosis undesensus testis selama periode Januari 2013 Desember 2015. Alat dan bahan yang digunakan adalah catatan rekam medik pasien undesensus testis, alat tulis menulis, instrumen hitung dan bahan referensi. Variabel penelitian yang diteliti yaitu:

1. Jumlah kasus

2. Umur

3. Sisi

4. Tindakan

Cara kerja dari penelitian ini yaitu mengumpulkan data dari catatan medik penderita undesensus testis di instalasi rekam medik Prof. Dr. R. D. Kandou Manado periode Januari 2013 - Desember 2015. Data kemudian diolah dan disajikan dalam bentuk teks dan tabel.

\section{HASIL PENELITIAN}

Berdasarkan penelitian retrospektif yang dilakukan, diperoleh 37 kasus undesensus testis di RSUP Prof. Dr. R. D. Kandou Manado selama periode Januari 2013 - Desember 2015.

Tabel 1 menunjukkan distribusi penderita undesensus testis tiap tahunnya. Pada tahun 2013 ditemukan 13 kasus (35,1\%), tahun 2014 ditemukan 13 kasus (35,1\%) dan tahun 2015 ditemukan 11 kasus (29,8\%) dengan total 37 kasus.

Tabel 1. Distribusi penderita undesensus testis per tahun

\begin{tabular}{ccc}
\hline Tahun & $\mathrm{N}$ & $\%$ \\
\hline 2013 & 13 & $35,1 \%$ \\
2014 & 13 & $35,1 \%$ \\
2015 & 11 & $29,8 \%$ \\
\hline Total & 37 & $100 \%$ \\
\hline
\end{tabular}

Tabel 2 menunjukkan distribusi penderita undesensus testis berdasarkan umur. Kelompok usia $0-6$ bulan sebanyak 23 penderita (62,1\%), $7-12$ bulan sebanyak 4 penderita (10,8\%), 13 18 bulan sebanyak 0 penderita (0\%), 19 24 bulan sebanyak 2 penderita $(5,4 \%)$ dan $>24$ bulan sebanyak 8 penderita (21,7\%). 
Tabel 2. Distribusi penderita undesensus testis berdasarkan umur

\begin{tabular}{ccc}
\hline $\begin{array}{c}\text { Umur (dalam } \\
\text { bulan) }\end{array}$ & $\mathrm{N}$ & $\%$ \\
\hline $0-6$ & 23 & $62,1 \%$ \\
$7-12$ & 4 & $10,8 \%$ \\
$13-18$ & 0 & $0 \%$ \\
$19-24$ & 2 & $5,4 \%$ \\
$>24$ & 8 & $21,7 \%$ \\
\hline Total & 37 & $100 \%$ \\
\hline
\end{tabular}

Tabel 3 menunjukkan distribusi penderita undesensus testis berdasarkan sisi testis yang terkena. Diperoleh sebanyak 7 kasus undesensus testis dextra (19\%), 9 kasus undesensus testis sinistra (24,3\%) dan 21 kasus undesensus testis bilateral (56,7\%).

Tabel 3. Distribusi penderita undesensus testis berdasarkan sisi

\begin{tabular}{ccc}
\hline Sisi & N & $\%$ \\
\hline Dextra & 7 & $19 \%$ \\
Sinistra & 9 & $24,3 \%$ \\
Bilateral & 21 & $56,7 \%$ \\
\hline Total & 37 & $100 \%$ \\
\hline
\end{tabular}

Tabel 4 menunjukkan distribusi penderita undesensus testis berdasarkan ada tidaknya tindakan dan jenis tindakan yang dilakukan sebagai berikut. Belum dilakukan tindakan pada 28 penderita undesensus testis (75,6\%), diberikan terapi hormonal pada 4 penderita (10,8\%) dan dilakukan orchidopeksi pada 5 penderita (13,6\%).

Tabel 4. Distribusi penderita undesensus testis berdasarkan ada tidaknya dan jenis tindakan

\begin{tabular}{lcc}
\hline \multicolumn{1}{c}{ Tindakan } & $\mathrm{N}$ & $\%$ \\
\hline Ada & & \\
Hormonal & 4 & $10,8 \%$ \\
Orchidopeksi & 5 & $13,6 \%$ \\
Tidak ada & 28 & $75,6 \%$ \\
\hline Total & 37 & $100 \%$ \\
\hline
\end{tabular}

\section{PEMBAHASAN}

Dari hasil penelitian retrospektif yang dilakukan di instalasi rekam medik RSUP Prof. Dr. R. D. Kandou Manado periode Januari 2013 - Desember 2015 ditemukan 37 pasien yang didiagnosis dengan undesensus testis.

Tabel 1 menunjukan distribusi penderita undesensus testis per tahun. Tahun 2013 dan 2014 memiliki jumlah penderita terbanyak yakni sebanyak 13 penderita. Terjadi sedikit penurunan pada tahun 2015, dimana jumlah kasus undesensus testis tahun 2015 ialah sebanyak 11 kasus.

Tabel 2 menunjukkan distribusi penderita undesensus testis berdasarkan kelompok umur. Pada penelitian ini ditemukan jumlah penderita terbanyak berada pada kelompok usia $0-6$ bulan yaitu sebanyak 23 penderita, diikuti kelompok usia > 24 bulan sebanyak 8 penderita, lalu kelompok usia 7 - 12 bulan dengan 4 penderita dan 2 penderita pada kelompok usia 19 - 24 bulan. Sementara itu tidak ditemukan penderita undesensus testis pada kelompok usia 13 - 18 bulan. Tingginya jumlah penderita pada kelompok usia $0-6$ bulan menunjukkan bahwa banyak kasus undesensus testis yang didiagnosa dini.

Tabel 3 menunjukkan distribusi penderita undesensus testis berdasarkan sisi. Kasus undesensus testis bilateral memiliki jumlah penderita terbanyak yaitu sebanyak 21 kasus (56,7\%). Menurut Abaci et al, undesensus testis paling banyak terjadi di sisi kanan, sebab testis kiri mengalami desensus lebih dahulu daripada testis kanan. ${ }^{12}$ Data epidemiologi di Amsterdam juga menunjukkan bahwa jumlah kasus undesensus testis unilateral dua kali lebih banyak dari jumlah kasus undesensus testis bilateral, dengan perbandingan kanan dan kiri 7:3. ${ }^{7}$ Faktor yang mendasari perbedaan hasil penelitian ini dan data epidemiologi yang ada adalah karena kebanyakan penderita berada pada kelompok usia 0 - 6 bulan, dimana pada 
usia ini testis kemungkinan belum turun secara spontan ke dalam skrotum., ${ }^{4,10}$

Tabel 4 menunjukkan distribusi penderita undesensus testis berdasarkan ada tidaknya dan jenis tindakan. Belum dilakukan tindakan pada hampir seluruh penderita, yakni 28 penderita. Kebanyakan penderita berada pada kelompok usia 0 - 6 bulan, sedangkan menurut teori, terapi hormonal dan orchidopeksi mulai dilakukan pada usia 6 bulan., ${ }^{4,12}$ Testis biasanya turun spontan sampai pada usia 6 bulan, sehingga hanya dilakukan evaluasi pada seluruh penderita kelompok usia ini. ${ }^{4}$

\section{KESIMPULAN}

Dari hasil penelelitian yang dilakukan di instalasi rekam medik RSUP Prof. Dr. R. D. Kandou Manado, dapat disimpulkan bahwa jumlah kasus undesensus testis selama periode Januari 2013 - Desember 2015 adalah sebanyak 37 kasus. Kelompok usia 0 - 6 bulan memiliki jumlah penderita terbanyak, yaitu sebanyak 23 penderita, dan angka kejadian undesensus testis bilateral lebih tinggi dari undesensus testis unilateral. Belum dilakukan tindakan pada kebanyakan penderita dan orchidopeksi merupakan tindakan operatif yang paling sering dilakukan.

\section{SARAN}

Kelengkapan pengisian status rekam medik sangat diperlukan untuk menunjang pendekatan penelitian yang lengkap, akurat dan informatif. Selain itu, perlu dilakukan penelitian lebih lanjut dan lebih rinci agar dapat memberi informasi mengenai perkembangan penyakit undesensus testis.

\section{DAFTAR PUSTAKA}

1. Winarta LH. Diagnosis dan tatalaksana undescended testis. EJurnal Medika Udayana. 2013;2(6):1099-116.

2. Coughlin MT. Cryptorchidism and male fertility: a study of the determinants of infertility among formerly cryptorchid and control men [dissertation]. [Pittsburgh]: University of Pittsburgh; 2004.

3. Nugroho D, Wahyudi I, Rodjani A. Profil pasien undesensus testis di rumah sakit cipto mangunkusumo Jakarta. J Indon Med Assoc. 2012;62(2):51-5.

4. Firdaoessaleh. Diagnosis dan penatalaksanaan undesensus testis. Majalah kedokteran Indonesia. 2007;57(2):33-6.

5. Kolon TF. Cryptorchidism. [cited 2015 Oct 4]. Available from: http://www.pediatricurologybook.com/ undesendedtestes.html

6. Cobellis G, Noviello C, Nino F, Romano M, Mariscoli F, Martino A, et al. Spermatogenesis and cryptorchidism. Frontiers in Endocrinology. 2014;5:1-4.

7. Burgu B, Baker LA, Docimo SG. Cryptorchidism. In: Gearhart JP, Rink RC, Mouriquand PD. Pediatric urology. 2nd ed. Amsterdam: Elsevier; 2010. p. 563-76.

8. Hughes IA, Acerini CL. Factors controlling testis descent. European Journal of Endocrinology. 2008;159:75-82.

9. Hutson JM, Hasthorpe S, Heyns CF. Anatomical and functional aspects of testicular descent and cryptorchidism. The Endocrine Society. 1997;18(2):259-80.

10. Hutson J. Undescended testes. 2011 Aug 4 [updated 2015 Feb; cited 2015 Oct 5]. Available from: https://www.andrologyaustralia.org/un descended-testes

11. Ptolemy. Cryptorchidism: a comprehensive clinical review [cited 2015 Oct 5]. Available from: http://www.ptolemy.ca/members/curre nt/Cryptorchidism/

12. Abacı A, Çatlı G, Anık A, Böber E. Epidemiology, classification and management of undescended testes: does medication have value in its treatment. J Clin Res Pediatr Endocrinol. 2013;5(2):65-72. 
13. MacKinnon AE. The undescended testis. Indian Journal of Pediatrics. 2005;72:429-32.

14. Virtanen HE, Bjerknes R, Cortes D, Jorgensen N, Meyts ER, Thorsson AV, Thorup J, et al. Cryptorchidism: classification, prevalence and longterm consequences. Ala Pediatrica. 2007;96:611-6. 